\title{
A WALL BETWEEN THE "PUBLIC" AND THE "PRIVATE": A COMMENT ON HIGHWOOD CONGREGATION OF JEHOVAH'S WITNESSES (JUDICIAL COMMITTEE) v WALL
}

\author{
MANNU CHOWDHURY*
}

\section{INTRODUCTION}

In Highwood Congregation of Jehovah's Witnesses (Judicial Committee) v Wall (Wall), ${ }^{1}$ the Supreme Court of Canada addressed a confounding problem of administrative law: what is the purpose and scope of judicial review, especially in relation to private actors? A church had expelled one of its members for alleged misconduct, at which point the excommunicated individual commenced an application to judicially review the church's decision. The Court of Queen's Bench of Alberta ${ }^{2}$ and a majority of the Alberta Court of Appeal $^{3}$ held that the courts had jurisdiction to review the church's decision. The Supreme Court, however, ruled that the issues raised in this case were antithetical to the object and ambit of judicial review. ${ }^{4}$ Writing for a unanimous court, Justice Rowe clarified that judicial review is a tool used for holding the state, and those exercising the state's delegated authority, accountable. ${ }^{5}$ Accordingly, the court found that it is inappropriate to subject private entities - such as churches-to judicial review. ${ }^{6}$

I argue that while Wall provided some helpful clarifications on the purpose of judicial review, it created a number of difficulties in determining the availability and scope of judicial review. First, Wall did not resolve the central challenge pertaining to the ambit of judicial review. Before Wall, the courts held that they could review the

Copyright $(2019$ by MANNU CHOWDHURY.

* Mannu Chowdhury holds a MSc (Oxford, 2013) and JD (Toronto, 2017). The author would like to thank several people who were integral to publishing this paper: Dahlia Shuhaibar, Justin Safayeni, and Madeeha Hashmi for their thorough and incisive comments on this paper; Ewa Krajewska for her encouragement to write on this topic; the editors of the Western Journal of Legal Studies for their comprehensive feedback; and Nabila F Qureshi for her substantive critiques of this paper and for her ongoing support on all pursuits.

${ }^{1} 2018$ SCC 26 [Wall SCC].

${ }^{2}$ Wall v Judicial Committee of the Highwood Congregation of Jehovah's Witnesses, 2016 ABCA 255 at para 11 [Wall ABCA].

${ }^{3}$ Ibid at para 29.

${ }^{4}$ Wall SCC, supra note 1 at para 22.

${ }^{5}$ Ibid at paras $13-14$.

${ }^{6} \mathrm{Ibid}$ at paras 20-22. 
conduct of public actors; the central issue was that the courts could not apply a test in a predictable manner in order to determine what makes an actor public. With Wall, the Supreme Court has shifted the focus from "public" actors to "state" agents as being the proper subjects of judicial review. However, the court in Wall does not provide any guidance on what constitutes a "state" agent. This poses challenges for both courts and litigants in determining whether judicial review is available in typical and borderline cases.

Second, the Supreme Court misinterprets the leading jurisprudence on the public-private distinction, which outlined the hallmarks of a "public" agent. The result is that the court significantly undermines - or worse, rejects - a body of helpful case law on the scope of judicial review.

Third, there is a disconnect between the Supreme Court's approach to judicial review in Wall and the function of the modern administrative state. On the one hand, the court stresses that judicial review is integral to the rule of law because it holds administrative actors accountable. On the other hand, the court outlines an approach that leaves quasi-public actors effectively immune from judicial review, even though the modern administrative state depends on them to meet the needs of ordinary people by providing and regulating a wide range of services.

Fourth, Wall potentially hinders the growth and application of Charter values. It has the unintended consequence of allowing quasi-public actors to disregard Charter values in their decision-making process since they are no longer subject to judicial review.

This case comment is divided into five parts. Sections one and two summarize the background of the case and Justice Rowe's reasons. Section three reviews the existing jurisprudence and considers the practical and conceptual implication of the ratio in Wall. Section four outlines the strengths of Wall, and, finally, section five evaluates the weaknesses of the decision.

\section{LOWER COURT FACTS AND DECISIONS}

Randy Wall, a realtor in Alberta, was a member of Highwood Congregation of Jehovah's Witnesses (the Church). ${ }^{7}$ In March 2014, he was summoned by the Judicial Committee of Elders (the Committee) to discuss his "alleged wrongdoings" and to receive "spiritual assistance." 8 During the meeting, Mr. Wall admitted to two instances of public drunkenness and to verbally abusing his wife during one such episode. ${ }^{9}$ However, Mr. Wall explained that he and his family were going through a difficult

\footnotetext{
${ }^{7}$ Wall ABCA, supra note 2 at para 3.

${ }^{8}$ Ibid at para 4.

${ }^{9} \mathrm{Ibid}$ at para 5.
} 
period, which precipitated his conduct. ${ }^{10}$ The Church had "disfellowshipped" his daughter; as a result, not only was the Wall family required to shun her, but they also had to evict her despite her being only fifteen years old. ${ }^{11}$

The Committee did not find Mr. Wall's explanation compelling. It ruled that Mr. Wall had not "sufficiently repented" for his conduct, and disfellowshipped him. ${ }^{12}$ The Committee ordered that Church members, including the Wall family, shun Mr. Wall. ${ }^{13}$ Beyond the emotional effects of shunning, being disfellowshipped had adverse financial effects on Mr. Wall. He claimed that he was unable to continue serving Jehovah's Witnesses as a realtor because of his expulsion from the Church. ${ }^{14}$

Mr. Wall appealed the decision to the Church's Appeal Committee and to the governing council for all Jehovah's Witnesses churches. ${ }^{15}$ These applications were also unsuccessful. ${ }^{16}$ Having exhausted all internal remedies, Mr. Wall filed an application to judicially review the Church's decision at the Alberta Court of Queen's Bench (the ABQB). ${ }^{17}$

The ABQB ruled that it had jurisdiction to hear whether Mr. Wall's "civil rights might have been affected" by the Committee's decision. ${ }^{18}$ A majority of the Court of Appeal of Alberta (the ABCA) agreed and upheld the chamber judge's ruling. ${ }^{19}$ The ABCA stated that insofar as religious organizations breach the rules of natural justice, the courts have jurisdiction to subject such decisions to judicial review. ${ }^{20}$ The dissenting judge, however, noted that the Church was a private actor and, therefore, could not be subject to judicial review. ${ }^{21}$

\section{DECISION OF THE SUPREME COURT OF CANADA}

Justice Rowe, for the Supreme Court, agreed with the dissenting judge of the $\mathrm{ABCA}$ and found that since the Church was a private body, its decision was not subject to judicial review. He provided three reasons for this conclusion.

\footnotetext{
${ }^{10}$ Ibid.

${ }^{11}$ Ibid.

${ }^{12}$ Ibid at para 6.

${ }^{13}$ Ibid.

${ }^{14}$ Ibid at para 62.

${ }^{15}$ Ibid at paras 7-8.

${ }^{16}$ Ibid.

${ }^{17} \mathrm{Ibid}$ at para 9.

${ }^{18}$ Wall SCC, supra note 1 at para 8.

${ }^{19}$ Wall ABCA, supra note 2 at para 29.

${ }^{20}$ Ibid at para 22.

${ }^{21}$ Ibid at para 41.
} 
First, the Supreme Court held that the decision of the Church cannot be the subject of a judicial review because it is contrary to the role of and rationale behind judicial review. ${ }^{22}$ Justice Rowe explained that judicial review is a "public law concept" that concerns "the relationship between the administrative state and the courts." 23 Applications for judicial review, according to Justice Rowe, are conduits through which the judiciary ensures that administrative actors do not exceed their delegated authority. The implication of this approach is that "judicial review is only available where there is an exercise of state authority and where that exercise is of a sufficiently public character." 24

Turning to Mr. Wall's case, Justice Rowe recognized that, among others, there were two lines of jurisprudence that implied that Mr. Wall's complaint could be subject to judicial review. ${ }^{25}$ Justice Rowe rejected this case law for the following reasons. ${ }^{26}$

The first line of case law erroneously established that "private Acts" operate as a statutory grant of authority to churches such that they are subject to judicial review. ${ }^{27}$ Justice Rowe held that this line of reasoning fails to account for the fact that "private Acts" are private in character and not subject to "public" scrutiny. ${ }^{28}$

The second line of case law provided that voluntary associations can be subject to judicial review if the association is "sufficiently public in nature." 29 For Justice Rowe, such cases do not adequately distinguish 'between 'public' in a generic sense and 'public' in a public law sense." ${ }^{30}$ For the purposes of judicial review, "a decision will be considered to be public where it involves questions about the rule of law and the limits of an administrative decision maker's exercise of power." ${ }^{31}$ Merely because a decision affects many people does not mean that "it is public in the administrative law sense of the term." 32

Having rejected these lines of case law, Justice Rowe found that there was no juridical basis to rule that Mr. Wall's allegations could be the subject of judicial review, since he was resorting to a public law concept to adjudicate his private dispute with a private voluntary association. ${ }^{33}$

${ }^{22}$ Wall SCC, supra note 1 at paras 2, 22.

${ }^{23}$ Ibid at para 13.

${ }^{24} \mathrm{Ibid}$ at para 14.

${ }^{25} \mathrm{Ibid}$ at para 17.

${ }^{26}$ Ibid.

${ }^{27}$ Ibid at para 18.

${ }^{28} \mathrm{Ibid}$ at para 20.

${ }^{29} \mathrm{Ibid}$ at para 19.

${ }^{30} \mathrm{Ibid}$ at para 20.

${ }^{31}$ Ibid.

${ }^{32}$ Ibid.

${ }^{33} \mathrm{Ibid}$ at para 22. 
The second reason Justice Rowe found the Church was not subject to judicial review was that there is no free-standing right to procedural fairness ${ }^{34}$ vis-à-vis decisions made by voluntary associations when such decisions do not impinge on one's civil or property rights. ${ }^{35}$ A party may seek judicial review of a voluntary association's decision only if the decision adversely affects legal duties owed by the association to the individual. ${ }^{36}$ In this case, the court found that there was no legal relationship (contractual, proprietary, etc.) between the Church and Mr. Wall's real estate business. ${ }^{37}$

Third, Justice Rowe stressed that the courts should be hesitant to opine on the justiciability of religious precepts. ${ }^{38}$ The Supreme Court has consistently stated that "the courts will not consider the merits of a religious tenet; such matters are not justiciable." 39 Justice Rowe, however, added an additional gloss to this proviso: interpreting procedural rules of a particular religious group may involve the interpretation of ecclesiastical doctrines, which the courts neither can nor should engage in. ${ }^{40}$

\section{PAST JURISPRUDENCE AND IMPLICATIONS OF THE SUPREME COURT'S HOLDING}

It is important to situate Wall within existing jurisprudence and to examine the conceptual and practical significance of the decision. Accordingly, this section outlines the existing case law on the public-private distinction in the law of judicial review and then unpacks the implications of Wall.

\section{Existing Case Law}

Prior to Wall, an expansive body of jurisprudence developed concerning when an actor could be subject to judicial review. ${ }^{41}$ The typical case on the public-private

\footnotetext{
${ }^{34}$ See McCaw v United Church of Canada (1991), 4 OR (3d) 481 (CA); Pederson v Fulton (1994), 45 ACWS (3d) 665, (Ct J (Gen Div)).

${ }^{35}$ Wall SCC, supra note 1 at para 24.

${ }^{36}$ Ibid at para 27.

${ }^{37}$ Ibid at para $28-29$.

${ }^{38}$ Ibid at para 36.

${ }^{39}$ Ibid at para 37.

${ }^{40}$ Ibid at para 38.

${ }^{41}$ See Alberta Soccer Association v Charpentier, 2010 ABQB 715; Port of Dalhousie Inc v Maltais, 2011 NBCA 84; Boucher v Métis Nation of Alberta Association, 2009 ABCA 5; Co-Operative Housing Federation of Canada $v$ York (Regional Municipality) (2009), 175 ACWS (3d) 564 (Div Ct); Wise v Legal Services Society, 2008 BCSC 255; Crasmariu v West Van Florist Ltd, 2006 BCPC 291; Ehrcke v Public Service Pension Board of Trustees, 2004 BCSC 757; Coombes v National Phoenix 1984 Firearms Information \& Communication Association, 2009 ABQB 566; Akhtar v Canadian Board for Certification
} 
distinction comprises a private actor who discharges duties that appear "public" in nature. In such cases, courts have struggled to articulate a coherent framework for determining circumstances in which a private body operates as a "public" one, such that its decisions can undergo judicial review. ${ }^{42}$

Before the Supreme Court's decision in Wall, the leading authority on the public-private distinction - and its underlying functional approach-was Air Canadav Toronto Port Authority ${ }^{43}$ (Air Canada). In this case, the Toronto Port Authority had issued bulletins about landing spots in Billy Bishop Airport, an island airport in Toronto. ${ }^{44}$ The bulletins limited Air Canada's landing spots and, instead, offered those spots previously belonging to it to Porter Airlines. ${ }^{45}$ The Federal Court of Appeal (the FCA) dismissed Air Canada's application for judicial review of the Toronto Port Authority's changes to its bulletins. ${ }^{46}$ The court found that, inter alia, the decision to alter the bulletins and the matters set out in them were "private" in character, such that the Toronto Port Authority could not be said to be acting as a "federal board, commission or other tribunal" pursuant to the Federal Courts Act. ${ }^{47}$ Accordingly, the court did not have jurisdiction to decide the matter.

In reaching this conclusion, the FCA provided a framework for analyzing when an actor was sufficiently "public" such that its conduct could be judicially reviewed. The relevant factors to consider included the following: (1) "the character of the matter for which review is sought"; (2) "the nature of the decision-maker and its responsibilities"; (3) "the extent to which a decision is founded in and shaped by law as opposed to private discretion"; (4) "the body's relationship to other statutory schemes or other parts of government"; (5) "the extent to which a decision-maker is an agent of government or is directed, controlled or significantly influenced by a public entity"; (6) "the extent to which a decision-maker is an agent of government"; (7) "the suitability of public law remedies"; and (8) "an 'exceptional' category of cases where the conduct has attained a serious public dimension." 48 The FCA stressed that the above

of Prosthetists and Orthotists, 2015 MBQB 46; Al-Ghamdi v College and Association of Registered Nurses of Alberta, 2017 ABQB 685; Lee v Yeung, 2012 ABQB 40.

42 This pattern does not appear unique to Canada as scholars have raised similar concerns with other jurisdictions. For discussions of this, see Mark Elliott, "Judicial Review's Scope, Foundations and Purposes: Joining the Dots" (2012) 1 NZLR 75; Mark Freedland, "The Evolving Approach to the Public/Private Distinction in English Law" in Mark Freedland \& Jean-Bernard Auby, eds, The Public Law/Private Law Divide (Oxford: Hart Publishing, 2006) at 93.

432011 FCA 347 [Air Canada].

${ }^{44} \mathrm{Ibid}$ at paras $17-20$.

45 Ibid.

46 Ibid at para 81.

${ }^{47}$ Ibid at paras 73-75.

${ }^{48}$ Ibid at para 60. 
factors were not a checklist. Rather, whether something was "public" depended on the facts and the "overall impression" of the courts. ${ }^{49}$

On balance, the Air Canada factors in and of themselves are instructive and consistent with how other common law jurisdictions approach the public-private distinction. ${ }^{50}$ In particular, the Air Canada framework laudably provides courts with indicators of what makes an actor "public" such that it can be judicially reviewed. ${ }^{51}$ The problem has been with how these factors are applied. Given the factors' purposive nature, the courts have applied them in varied ways, thus engendering a complex and often perplexing body of jurisprudence. Actors that intuitively may seem "public" were not deemed public in several cases pursuant to the Air Canada factors and vice versa. To unpack this point, some examples from the existing case law are helpful:

- Schools: A private school's decision to expel a student for violating its code of conduct was found to be "private" because, inter alia, "the expulsion decision [was] shaped by private law rather than public law." 52 The Court of Appeal for Ontario found that expulsion as a disciplinary mechanism was provided for by the contract between the school and the student, and so it could not be subject to judicial review. ${ }^{53}$

- Universities: A student union's decision to refuse to officially recognize a group advocating for men's issues, ${ }^{54}$ a pro-life group, ${ }^{55}$ and a group that "speaks for the weak" 56 as "student groups" on a university campus could not be judicially reviewed because the impugned student union was a private student organization. Further, a university's decision to grant wage increases to nonunionized employees during a wage freeze was not appropriate for judicial

\footnotetext{
${ }^{49}$ Ibid; Setia v Appleby College, 2013 ONCA 753 at para 33 [Setia].

${ }^{50}$ Professor Paul Daly confirms that the following cases demonstrate that other common law courts have developed factors similar to Air Canada to adjudicate issues surrounding the public-private distinction: Mercury Energy Ltd v Electricity Corporation of New Zealand, [1994] 1 WLR 521 at 526 (PC); O'Donnell v Tipperary (SR) County Council, [2005] 2 IR 483 at 487 (Irish SC); Neat Domestic Trading Pty Ltd v AWB Ltd (2003), 216 CLR 277 (Australia HC) at paras 27-29; CECA Institute Pty Ltd \& Anor v Australian Council for Private Education and Training, [2010] VSC 552 at paras 101-13; Mita Michael Ririnui v Landcorp Farming Ltd, [2016] NZSC 62. For further discussion of this, see Paul Daly, "Right and Wrong on the Scope of Judicial Review: Highwood Congregation of Jehovah's Witnesses (Judicial Committee) v Wall" (2018) 31:3 Can J Admin L \& Prac 339 at 342.

${ }^{51}$ Daly, supra note 50 at 342.

${ }^{52}$ Setia, supra note 49 at para 40.

${ }^{53}$ Ibid.

${ }^{54}$ See Arriola v Ryerson Students' Union, 2018 ONSC 1246 at paras 5, 23, 33, 66.

${ }^{55}$ See Zettel v University of Toronto Mississauga Students' Union, 2018 ONSC 1240 at paras 5, 84-88.

${ }^{56}$ Naggar $v$ The Student Association at Durham College and UOIT, 2018 ONSC 1247 at paras 27, 67.
} 
review because compensation is an "essentially private matter." ${ }^{, 57}$ Conversely, a university's decision to raise ancillary fees on students during a governmental freeze on tuition fees was subject to judicial review because it was exercising an "extremely important public duty" in setting tuition fees. ${ }^{58}$

- Political Parties: The nomination process for political party candidates was subject to judicial review because, among other things, "the decision of the [party] in selecting their leader carries with it some considerable importance for the voting public." ${ }^{59}$ However, the Ontario Divisional Court later refused to follow the above decision: in a case involving a political party disciplining its candidates for leaking confidential information, the court ruled that a political party cannot be judicially reviewed because it is a private actor and a voluntary association. ${ }^{60}$

- Hospitals: A hospital's decision to suspend cancer researchers because of alleged misconduct related to their research was subject to judicial review given the public nature of the hospital and the research. ${ }^{61}$

- Sports Leagues: The Ontario Soccer Association's policies on the eligibility of the province's soccer players were subject to judicial review since these policies had a "serious effect on the interests of a broad segment of the public." 62 When the Ontario Association of Basketball Officials - a voluntary and private not-for-profit association-sanctioned a high school basketball team coach for blaming referees, the court found that it had jurisdiction to judicially review the matter because barring the coach would have adverse effects on the coach's identity and the team's playoff hopes. ${ }^{63}$ Similarly, the decision of a regional soccer association to discipline a team for recruiting girls older than thirteen as players was found to be appropriate for judicial review because it failed to provide adequate notice and opportunities to be heard. ${ }^{64}$ On the other hand, the

\footnotetext{
${ }^{57}$ Association of Professors of the University of Ottawa v University of Ottawa, 2018 ONSC 1191 at paras 3, 10-14. See also Grant v Ryerson Students' Union, 2016 ONSC 5519.

${ }^{58}$ Attaran v University of British Columbia (1998), 77 ACWS (3d) 99 at para 46-47 (BCSC). See also Courchene v Carleton University Students'Association Inc, 2016 ONSC 3500.

${ }^{59}$ Graff v New Democratic Party, 2017 ONSC 3578 at para 12. However, Graff directly contradicted Knox v Conservative Party of Canada, 2007 ABCA 295 at paras 26-27 [Knox].

${ }^{60}$ See Trost $v$ Conservative Party of Canada, 2018 ONSC 2733 at paras 28-35; Knox, supra note 59; Longley $v$ Canada $(A G), 2007$ ONCA 852 at para 71.

${ }^{61}$ See Asa v University Health Network, 2016 ONSC 439 at paras 28-35 [Asa].

${ }^{62}$ West Toronto United Football Club v Ontario Soccer Association, 2014 ONSC 5881 at paras 23-29 [West Toronto].

${ }^{63}$ See Gymnopoulos v Ontario Association of Basketball Officials, 2016 ONSC 1525 at para 40.

${ }^{64}$ See Islington Rangers Soccer League v Toronto Soccer Association, 2017 ONSC 6229 at paras 77-78. See also St Andrew's College v York Region Athletic Assn (2000), 95 ACWS (3d) 415 (Ont Sup Ct).
} 
decision of the North York Hockey League to ban parents from attending their children's hockey games due to their use of offensive language could not be judicially reviewed because there was no "exercise of power emanating from the legislature" at bar. ${ }^{65}$

It goes without saying that different factual circumstances will result in different applications of the Air Canada factors. My objection is not that the application of the factors in the above cases were at large erroneous. Rather, the cases highlight the broader unpredictability of the public-private jurisprudence. The courts have applied the eight Air Canada factors without providing significant guidance on when and what sort of factual matrix makes one or more of the factors especially salient. As such, there is considerable variance in, for example, how disciplinary policies of a political party and a private school are treated versus those of a sports league. The result is significant uncertainty for everyone involved.

\section{Implications of Wall}

Against this backdrop of jurisprudential uncertainty, Wall has two immediate effects-one practical and one conceptual. The practical implication is that certain actors, such as sports leagues, that were formerly subject to judicial review are no longer subject to it. If only "state" agents are the appropriate subjects for judicial review, it follows that, for example, political parties and administrators of sports leagues are no longer subject to judicial review. Hence, Wall has a significant effect on how parties conduct their litigation: to try to vindicate their rights, parties would have to increasingly rely on private law remedies, primarily in contract and tort.

The conceptual effect of Wall is that it may signal an attitudinal shift in how the Supreme Court approaches administrative law. Before Wall, reviewing courts took a functional approach when analyzing whether an actor may be subject to judicial review, focusing on whether the actor was engaged in "public" conduct rather than whether the impugned actor was formally "public." As Professor Eskridge has observed, formalism is about "bright-line rules that seek to place determinate, readily enforceable limits on public actors ..." whereas "functionalism [is] associated with standards or balancing tests that seek to provide public actors with greater flexibility." ${ }^{66}$ In many ways, Canadian administrative law is about finding the right balance between these differing approaches.

\footnotetext{
${ }^{65}$ Milberg v North York Hockey League, 2018 ONSC 496 at para 32. See also Erin Mills Soccer Clubv Ontario Soccer Association, 2016 ONSC 7718; Adams v Canada (AG), 2011 ONSC 325.

${ }^{66}$ William N Eskridge Jr, "Relationships between Formalism and Functionalism in Separation of Powers Cases” (1998) 22:1 Harv JL \& Pub Pol'y 21 at 21.
} 
In Professor MacLauchlan's view, a thread of functionalism underwrites Canadian administrative law. ${ }^{67}$ That may be changing. While it is premature to conclude with certainty, Wall hints that the Supreme Court is increasingly comfortable using a more formalist lens to analyze administrative law challenges. It remains to be seen whether the court will continue with this formalist approach in the trilogy on standard of review decision, expected to be released later this year. ${ }^{68}$

Ultimately, my intention in underscoring the above two implications is descriptive in nature. The takeaway for readers is simply this: Wall potentially signals changes for both how litigants may vindicate their rights and the conceptual framework that animates the Supreme Court's reasoning on administrative law problems. The broader questions that these implications raise unfortunately remain beyond the scope of this case comment-namely, is something intrinsically lost as a result of having to rely on private law remedies as opposed to public law remedies? And is a formalist approach to administrative law "better" than a functional approach?

\section{STRENGTHS OF THE DECISION}

Wall has three key strengths: (1) elucidating the first principles of judicial review; (2) reaffirming the existing law on procedural fairness; and (3) stressing a balanced approach to adjudicating matters that contain a religious aspect.

First, Wall is laudable for its clarification of the first principles of judicial review. While judicial review has been at the heart of many recent Supreme Court decisions, ${ }^{69}$ the court seldom discusses the purpose behind judicial review in those cases. Wall is a different story. Justice Rowe succinctly captures the purpose of judicial review, its significance to the rule of law and, ultimately, its power in holding the administrative state accountable. By way of illustration, consider the following passages from the decision:

The purpose of judicial review is to ensure the legality of state decision making ... . Judicial review is a public law concept that allows s. 96 courts to

\footnotetext{
${ }^{67} \mathrm{H}$ Wade MacLauchlan, "Transforming Administrative Law: The Didactic Role of the Supreme Court of Canada" (2001) 80 Can Bar Rev 281 at 290-91. See also John Willis, "Three Approaches to Administrative Law: The Judicial, the Conceptual, and the Functional" (1935-1936) UTLJ 53 at 73-78. ${ }^{68}$ See Vavilov $v$ Canada (Citizenship and Immigration), 2017 FCA 132, leave to appeal to SCC granted, 37748 (10 May 2018); Bell Canada v Canada (AG), 2017 FCA 249, leave to appeal to SCC granted, 37896 (10 May 2018); National Football League v Canada (AG), 2017 FCA 249 leave to appeal to SCC granted, 37897 (10 May 2018).

${ }^{69}$ See Trinity Western University v Law Society of Upper Canada, 2018 SCC 33; Groia v Law Society of Upper Canada, 2018 SCC 27; Ktunaxa Nation v British Columbia (Forests, Lands and Natural Resource Operations), 2017 SCC 54; Chippewas of the Thames First Nation v Enbridge Pipelines Inc, 2017 SCC 41; Clyde River (Hamlet) v Petroleum Geo-Services Inc, 2017 SCC 40.
} 
"engage in surveillance of lower tribunals" in order to ensure that these tribunals respect the rule of law ... . The state's decisions can be reviewed on the basis of procedural fairness or on their substance. The parties in this appeal appropriately conceded that judicial review primarily concerns the relationship between the administrative state and the courts. Private parties cannot seek judicial review to solve disputes that may arise between them; rather, their claims must be founded on a valid cause of action, for example, contract, tort or restitution.

... Judicial review is only available where there is an exercise of state authority and where that exercise is of a sufficiently public character. Even public bodies make some decisions that are private in nature - such as renting premises and hiring staff — and such decisions are not subject to judicial review ... . In making these contractual decisions, the public body is not exercising "a power central to the administrative mandate given to it by Parliament," but is rather exercising a private power ... . Such decisions do not involve concerns about the rule of law insofar as this refers to the exercise of delegated authority. ${ }^{70}$

The above passages underscore that Wall is, arguably, the clearest Supreme Court proclamation of the decade since the release of Dunsmuir $v$ New Brunswick ${ }^{71}$ regarding why judicial review is significant from the perspective of both rights protection and the democratic functioning of Canada.

Second, the Supreme Court remains true to the long-established principle that there is no free-standing right to procedural fairness. ${ }^{72}$ Rather, procedural fairness is accorded when there is a cognizable legal right at issue, including but not limited to rights in tort, contract, and property. As commentators have noted, Wall raised "hard facts" - namely, a sympathetic litigant whose life was considerably altered as a result of the Church's decision. ${ }^{73}$ This sense of unfairness may have influenced the courts below to find that the Church denied Mr. Wall procedural fairness. The Supreme Court, however, resisted the temptation to make the right to procedural fairness an independent right writ large.

\footnotetext{
${ }^{70}$ Wall SCC, supra note 1 at paras 13-14.

712008 SCC 9.

${ }^{72}$ See Lakeside Colony of Hutterian Brethren v Hofer, [1992] 3 SCR 165; Ukrainian Greek Orthodox Church of Canada $v$ The Trustees of Ukrainian Greek Orthodox Cathedral of St Mary the Protectress, [1940] SCR 586; 3 DLR 670.

73 Justin Safayeni, "Religious Organizations' Membership Decisions are Subject to Judicial Review" (21 December 2016), online (blog): CanLII Connects <canliiconnects.org/en/commentaries/44366> [perma.cc/WRY8-QURT].
} 
Third, the Supreme Court struck the right balance between encouraging restraint on the part of the judiciary when adjudicating religious disputes and ensuring that religious organizations are not beyond the grasp of the law. On the one hand, the court stressed a cautious approach to judicially reviewing the conduct of religious institutions. $^{74}$ Prior to Wall, there was burgeoning case law ${ }^{75}$ and academic scholarship $^{76}$ that endorsed approaches to judicially intervening in religious disputes. Justice Rowe correctly concluded that the courts neither have the expertise nor the legitimacy to engage in such analysis. ${ }^{77}$ On the other hand, the Supreme Court did not abandon all oversight of religious groups, suggesting that where concrete legal rights are at stake, reviewing courts will intervene even if the dispute has a religious aspect. ${ }^{78}$ In the case of Mr. Wall, the court was justified in finding that a judicial determination of his dispute required opining on the grounds and method of expulsion that the Church uses. This ultimately requires the court to delve into theological dogma.

In sum, the Supreme Court in Wall was attuned to the unique predicaments faced by Mr. Wall. However, it was not persuaded that these issues warranted departing from the established principles concerning how procedural fairness is conceptualized and the way courts approach disputes with underlying ecclesiastical components.

\section{WEAKNESSES OF THE DECISION}

Despite the Supreme Court's sound approach on issues such as procedural fairness, Wall has four weaknesses. These weaknesses range from misconstruing the existing body of jurisprudence to rendering a decision with conceptual tensions. The result is that Wall makes the law of judicial review more complex.

\section{Availability of Judicial Review: Complicating an Already Complex Analysis}

First, Wall obfuscates an already complex question: when can parties seek judicial review? Wall exacerbates the uncertainty regarding whether judicial review is available in both "typical" and "borderline" cases. This creates conceptual inconsistencies and has concrete effects on people's ability to vindicate their rights ${ }^{79}$ and the ability of lawyers to provide sound advice.

\footnotetext{
${ }^{74}$ Wall SCC, supra note 1 at paras 36-37.

${ }^{75}$ See Sandhu v Siri Guru Nanak Sikh Gurdwara of Alberta, 2015 ABCA 101; Hart v Roman Catholic Episcopal Corporation of the Diocese of Kingston, in Canada, 2011 ONCA 728.

${ }^{76}$ Patrick Hart, “Justice for (W)all: Judicial Review and Religion” (2017) 43:1 Queen's LJ 1.

${ }^{77}$ Wall SCC, supra note 1 at paras 36-38.

${ }^{78} \mathrm{Ibid}$ at paras 36, 39.

${ }^{79}$ In saying that people's ability to vindicate their rights is constrained, my suggestion is not that there is something intrinsically beneficial about pursuing an application for judicial review and that a private law remedy by comparison is an ineffective option. Rather, my point is a modest one: since Wall narrows
} 
As explained above, the decisions rendered prior to Wall followed Air Canada and generally held that insofar as one sought to review a public actor's conduct, judicial review was available. While the eight factors set out in Air Canada have provided some helpful guidance, reviewing courts have struggled to weigh and apply these factors in a predictable or consistent manner when determining whether an entity is "public" for the purposes of judicial review. The result is a disjointed body of case law in terms of which decisions are judicially reviewable between different institutions, ${ }^{80}$ and even within the same institution. ${ }^{81}$

Wall made this jurisprudence more cumbersome to apply. Instead of clarifying the debate on what counts as "public," 82 the Supreme Court stated that only state action is subject to judicial review. But, as Professor Daly notes, the problem is that the court does not explain what counts as the "state." ${ }^{83}$ Instead, this contested term ${ }^{84}$ is treated as a self-evident truth whose meaning is facially obvious. Consequently, Professor Daly argues that the Wall approach to the scope of judicial review is essentially "questionbegging": it states that judicial review is about scrutinizing "state" conduct without telling readers what constitutes the "state." 85

what can be subject to judicial review, litigants may have fewer options to vindicate their rights. Whereas before individuals might have been able to choose between a private law remedy and a public law remedy, Wall may make it such that individuals in certain circumstances can only resort to private law remedies. This narrowing of litigation options may impede how people go about enforcing their rights.

${ }^{80}$ As the case summaries cited earlier in section III of this case comment illustrate, disciplinary actions of sports administrators in Gymnopoulos v Ontario Association of Basketball Officials, supra note 63, generally, were found to be judicially reviewable, but similar sanctions imposed by political parties in Trost $v$ Conservative Party of Canada, supra note 60, generally, were not.

${ }^{81}$ A university's decision to give wage increases during a wage freeze could not be judicially reviewed (Association of Professors of the University of Ottawa v University of Ottawa, supra note 57, generally) but a tuition increase during a tuition freeze was judicially reviewable (Attaran v University of British Columbia (1998), supra note 58, generally). Moreover, a government procurement process regarding "agency stores" in the alcohol industry was found to be judicially reviewable in one case (Dignam v New Brunswick Liquor Corp, 2014 NBQB 109) but not in another (2169205 Ontario Inc o/a Lefroy Freshmart $v$ Liquor Control Board of Ontario, 2011 ONSC 1878) despite nearly identical circumstances.

${ }^{82}$ This paper remains agnostic about the definition of the words "public" and "private" for the purposes of judicial review. Given the wide ambit of administrative function that a court may be called on to judicially review, I agree with Professor Daly that a flexible approach akin to Air Canada is sensible. The FCA's words from Air Canada are instructive on this point: "[I]t may be unwise to define the publicprivate distinction with precision. The 'exact limits' of judicial review have 'varied from time to time' to 'meet changing conditions.' The boundaries of judicial review, in large part set by the public-private distinction, have "never been and ought not to be specifically defined." (Air Canada, supra note 43 at para 58). For further discussions of this, see Daly, supra note 50 at 342.

${ }^{83}$ Daly, supra note 50 at 343.

${ }^{84}$ Donald JM Brown \& the Honourable John M Evans, Judicial Review of Administrative Action in Canada (Toronto: Carswell, 2009) at 1:2252.

${ }^{85}$ Daly, supra note 50 at 343. 
While I agree with Professor Daly's critique, I add that the practical import of this "question-begging" approach is significant and thus far remains unaddressed in the literature. In particular, Justice Rowe's approach has the potential to upend settled law and make it harder for both litigants and the courts to manage borderline judicial review cases. The following analysis considers each issue in turn.

"Settled" cases refer to case law where the courts have in large part recognized that an actor is subject to judicial review, even though that actor may not be a formal administrative delegate of a ministry. In these circumstances, the lack of clarity on what makes an agent a "state" entity in Wall has the potential to muddle settled cases on the scope of judicial review. To unpack this point, consider Asa v University Health Network (Asa) ${ }^{86}$

In Asa, a group of cancer researchers committed alleged misconduct under University Health Network's (UHN) internal research policy. As a result, UHN's President and CEO upheld a decision of its investigative committee to temporarily suspend the researchers. The Ontario Superior Court (the ONSC) found that this matter could be subject to judicial review because, among other reasons, the research "affect[ed] the medical protocols used in the treatment of cancer for the people of Ontario" 87 and UHN operated as a research facility pursuant to the Public Hospitals Act. ${ }^{88}$ In other words, one way to interpret Asa is this: the ONSC, by applying the Air Canada factors, was attuned to the fact that UHN is not a state actor in the same way as the Toronto Police Service is a state agent. However, for the ONSC, UHN had a sufficient nexus with the state such that its decisions could be scrutinized under judicial review.

Fast-forward to Wall and the sort of reasoning found in Asa is in doubt. Because Wall says that only state entities are subject to judicial review without telling us anything more, we do not know whether quasi-public actors, such as the hospital in Asa, are still subject to judicial review. Wall is silent on the sort of relationship that an administrative body needs to have with the state to trigger judicial review. This silence endangers the settled law where courts have concluded that some quasi-public agents may be judicially reviewed. In other words, a natural reading of Wall implies that if an actor is a formal state actor (such as the police), it is subject to judicial review. That answer, however, does not elucidate whether (and under what conditions) quasi-public actors might be subject to judicial review and if the existing case law where they are judicially reviewed is still "good" law under Wall.

Put another way, Asa by no means cured the overall uncertainty about how the Air Canada factors would be applied to a new factual matrix. What it did do, however,

\footnotetext{
${ }^{86}$ Asa, supra note 61.

${ }^{87}$ Ibid at para 31.

${ }^{88}$ RSO 1990, c P.40.
} 
was establish that hospitals might be judicially reviewed, even if they do not have all of the traditional hallmarks of the "state." Asa is one of the few islands of certainty in an otherwise vast sea of unpredictability. Wall challenges the core holding in Asa: whereas Asa was about making hospitals subject to judicial review by examining the degree of their closeness to the state, Wall says that only state agents are subject to judicial review. In the process, Wall implies that looking at the degree of closeness is a flawed exercise.

Wall also complicates the analysis for "borderline" cases pertaining to the scope of judicial review. A "borderline" dispute involves cases where it is arguable as to whether the court should exercise its jurisdiction to judicially review the decisions of a quasi-state actor. To illustrate the issues that may arise, consider the following hypothetical.

Imagine a partnership formed with a corporation to privatize a portion of Toronto's water supply. Upon privatization, the company decides to modify the existing water supply methods. This results in communities experiencing occasional water shortages and the discovery that the limited water they do receive is of poorer quality. In this context, a court may be asked to judicially review the water company's decision. The question is: can it be reviewed under Justice Rowe's approach in Wall ${ }^{89}$

Under Justice Rowe's approach, it is likely that the courts would not have the jurisdiction to judicially review the water company's conduct. Absent an express statutory grant to supply water-which might be atypical in a public-private partnership - it would be difficult to characterize a private utility corporation as a "state" actor when its primary imperative is to maximize its profits for its private shareholders by selling water.

Intuitively, however, the failure to judicially review the water company seems inadequate. Since water is an invaluable public good, the courts would likely be inclined to rule that the water company was exercising "state" authority. However, the problem is that Wall provides no insight into what makes an impugned decision "statelike." This leaves courts in the difficult position of divining principles and having to opine on potentially trite points, such as the importance of water.

Wall implemented an approach that seeks to eliminate the borderline cases concerning the scope of judicial review. However, such cases are a permanent feature of the administrative law terrain because of the sheer breadth and depth of the tasks that

\footnotetext{
${ }^{89} \mathrm{I}$ recognize that in such contexts the affected individuals may have private law recourses available to them. And while they may pursue such remedies, the thrust of the hypothetical is to ask what would happen if they sought public law remedies. In other words, the mere fact that private law remedies are available is not in and of itself determinative of the question of whether public law remedies are and should be available as well. The existence of one does not automatically extinguish the existence of and the need for the other.
} 
administrative actors perform and the many ways in which the true "state" chooses to structure and deliver various services to the public. In this context, it would have been better to strengthen the judicial toolkit by outlining factors - such as indicators of what makes an actor "state"-like - that the courts could rely on to address questions of judicial review, as opposed to merely shrinking the ambit of judicial review.

\section{Misinterpreting Air Canada}

The second problem with Wall is the Supreme Court's misinterpretation of existing case law. As opposed to bolstering the strengths of Air Canada-the seminal decision on the public-private distinction — and addressing its key weaknesses, the court misreads this case and its related jurisprudence. The result is one of uncertainty: at best, the court has, as Professor Daly stated, "marginaliz[ed]" Air Canada, and at worst it is no longer "good" law. Either way, it is unfortunate that Air Canada's legacy is complicated as a result of a narrow reading of its purposive approach.

Justice Rowe observes that Air Canada and the cases following its approach are a source of confusion concerning the ambit of judicial review. ${ }^{90} \mathrm{He}$ notes that these cases conflate the word "public" in its lay sense with its meaning in administrative law. ${ }^{91}$ In particular, the Supreme Court states that the Air Canada line of jurisprudence arrives at the following incorrect conclusion: because a significant number of people are affected by a decision - which is a consideration in Air Canada - the decision-maker is "public" and subject to judicial review. ${ }^{92}$ In the court's view, the Air Canada approach is to be blamed for this muddled understanding of the word "public" and, in turn, the confusion surrounding the scope of judicial review.

Justice Rowe's critique of the use of the word "public" stems from a narrow reading of Air Canada. While the impact of a decision on the populace is a factor in the FCA's enumerated list, it is only one factor among eight in determining whether an agent is "public" for the purposes of judicial review. ${ }^{93}$ The other factors examine diverse issues such as the character of the dispute and the nature of the body making the decision. ${ }^{94}$ This implies that the Air Canada factors are anything but reductive. In determining whether a decision-maker is "public" for the purposes of judicial review, the courts must consider a wide range of issues when applying the Air Canada factors; ${ }^{95}$

\footnotetext{
${ }^{90}$ Wall SCC, supra note 1 at paras 20-21.

${ }^{91}$ Ibid at para 20.

92 Ibid.

${ }^{93}$ See Adventure Tours Inc v St John's Port Authority, 2012 FC 305 ("[n]o one [Air Canada] factor is determinative ..." at para 20).

${ }^{94}$ Air Canada, supra note 43 at para 60.

95 Brown \& Evans, supra note 84 at 1:2252.
} 


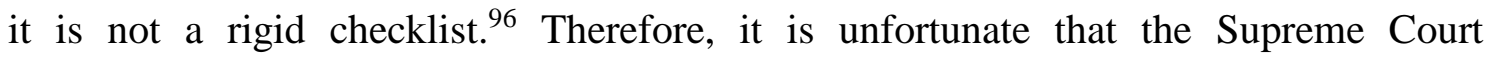
interpreted a highly purposive, multifactorial test as turning on one factor.

Moreover, the factor of impact on a broad segment of the population is evoked only for "an 'exceptional' category of cases where the conduct has attained a serious public dimension." 97 This is effectively a residual category envisaged by the Air Canada court. ${ }^{98}$ As such, it was arguably not intended to trump all of the other factors listed in Air Canada. In any event, even if this factor was playing an outsized role in the court's estimation, that issue could be addressed by emphasizing that it ought to be rarely invoked (or even eliminating it from the list of factors), rather than questioning the Air Canada framework in its entirety.

The result of the Supreme Court's narrow reading of Air Canada is further uncertainty. That is, Justice Rowe's approach can be interpreted in one of two ways. On the one hand, Professor Daly maintains that Wall "marginaliz[es]" Air Canada, effectively questioning its utility and characterizing it as a case about opining on whether an actor is a federal board, commission, or tribunal pursuant to the Federal Courts Act. ${ }^{99}$ Alternatively, Air Canada could be read in a much starker way: given that the court finds Air Canada is a source of confusion concerning the scope of judicial review, ${ }^{100}$ narrows Air Canada's commonly understood ratio, ${ }^{101}$ and questions a key component of the Air Canada framework, ${ }^{102}$ one may interpret Wall as overturning Air Canada. Either way, Wall undermines the juridical import of Air Canada. This is an unfortunate occurrence: Air Canada is weakened due to a narrow reading of its purposive approach. In the process, the current status of Air Canada is left unclear both for the courts and students of administrative law. ${ }^{103}$

\footnotetext{
${ }^{96}$ Air Canada, supra note 43 at para 60.

${ }^{97}$ Asa, supra note 61 at paras 28-30.

${ }^{98}$ West Toronto, supra note 62 at para 20.

${ }^{99}$ Daly, supra note 50 at 342-43.

${ }^{100}$ Wall SCC, supra note 1 at para 21.

${ }^{101}$ Justice Rowe states that Air Canada is a case about whether a certain public entity was subject to judicial review by the Federal Court, not about the general scope of judicial review (Daly, supra note 50 at 341-42). Professor Daly argues, however, that there is support in cases (such as Setia, supra note 49, generally) for understanding Air Canada as opining broadly on the ambit of judicial review.

102 See Wall SCC, supra note 1 at para 20. The court doubts whether "impact[ing] a broad segment of the public" means that a decision ought to be subject to judicial review. In Air Canada, the FCA stated that this was a factor that courts should consider in weighing whether to exercise its judicial review authority. ${ }^{103}$ Following Wall, trial courts have generally cited Wall and then proceeded to consider the Air Canada factors. Whether appellate courts will endorse a similar approach remains to be seen. But for now, it appears that Air Canada has been marginalized (Daly, supra note 50 at 343) but not deemed "bad" law. The recent cases on this issue are as follows: Beaucage v Métis Nation of Ontario, 2019 ONSC 633 at paras 22-26; Aquatech v Alberta (Minister of Environment and Parks), 2019 ABQB 62 at paras 8-10;
} 
Ultimately, Air Canada and its related case law are not without their tensions. ${ }^{104}$ Nevertheless, Air Canada had laid the groundwork for conceptualizing how judicial review would apply to quasi-public bodies. Rather than working to resolve and address tensions found within this rich body of jurisprudence, Wall raises doubts about the leading authority and, in the process, complicates a helpful line of jurisprudence without deeply engaging with it.

\section{A Gulf Between the Ratio and How Administrative States Function}

The third weakness in Wall is the disconnect between the Supreme Court's view of the importance of judicial review and the operation of the modern administrative state.

Justice Rowe rightly points out that the purpose of judicial review is to ensure that when the administrative state delegates authority to its agents, those agents exercise that authority pursuant to their delegated powers. ${ }^{105}$ Judicial review is a conduit for ensuring that the rule of law is respected and upheld.

This view must be considered alongside the realities of how the modern administrative state functions. As former Chief Justice McLachlin has explained, modern states are premised on administrative agents - both those that are formally "public" and those that are "private"-implementing and enforcing policies that were once the sole province of the state. ${ }^{106}$ The evolution of the administrative state has been such that public-private partnerships are integral to the state meeting the needs of ordinary people in areas that include health care and education. ${ }^{107}$ Wall seems removed from the reality that the administrative state requires quasi-public actors - and perhaps even technically "private" ones - to discharge its duties.

At the same time, the court in Wall insists that administrative actors must be held accountable to maintain the rule of law. ${ }^{108}$ This focus is at odds with the approach in Wall that gives courts the jurisdiction to judicially review only official state agents. Accountability and rule of law concerns are best advanced through a framework that

Strauss v British Columbia (Minister of Public Safety), 2018 BCSC 1414 at paras 56-58; C \& D Septic Ltd v Prince Albert, 2018 SKQB 185 at paras 16-18.

${ }^{104}$ Caleb O'Fee, "A New Perspective on the Public-Private Divide? Justiciability of Government Contracting Decisions Following Ririnui and Problem Gambling" (2018) 49:1 VUWLR 133 at 148-49.

${ }^{105}$ Wall SCC, supra note 1 at paras 13-14.

${ }^{106}$ Beverley McLachlin, "Administrative Tribunals and the Courts: An Evolutionary Relationship," Remarks, (last modified 28 February 2017), online: Supreme Court of Canada <www.scc-csc.ca/judgesjuges/spe-dis/bm-2013-05-27-eng.aspx> [perma.cc/NZ7Z-X7TJ].

${ }^{107}$ See Kevin J Ryan, "Public-Private Partnerships: Delivering Health Care, Education and Municipal Servicing" (2007) 35 MPLR (4th) 179 at 179; Doug Sanders, "Public Private Partnerships: A Procurement Panacea?" (2012) J Can College of Construction L 53 at 53.

${ }^{108}$ Wall SCC, supra note 1 at paras 13-14. 
subjects both formally public and quasi-public bodies to judicial review. Indeed, if applications for judicial review matter because they hold the state accountable by ensuring that its agents act within their jurisdiction, then it is logical to create a legal approach that holds all agents accountable — both those that are officially state agents and those that are not formally "state" agents but which nevertheless perform state functions.

Given that the Supreme Court's decision in Wall was attuned to the importance of judicial review and its relationship to the rule of law, it is surprising that the court endorsed an approach that narrows the scope of judicial review and could leave quasipublic agents unaccountable.

\section{A Lack of Clarity Regarding Charter Values}

Wall potentially diminishes the role of Charter values in relation to quasi-public actors. The Supreme Court has consistently stated that administrative bodies must act in accordance with Charter values. ${ }^{109}$ This has meant that quasi-public bodies have also sought to act in the spirit of the Charter. For instance, consider the British Columbia Court of Appeal's (the BCCA) decision in BC Civil Liberties Association v University of Victoria $(B C C L A) .{ }^{110}$ In that case, the University of Victoria prohibited a pro-life student group from holding demonstrations on campus. The student group argued before the BCCA that, inter alia, the University's policy breached the Charter value of freedom of expression. ${ }^{111}$ Given that the impugned University policy was revised by the time the case was heard, the BCCA ruled that the case was moot. ${ }^{112}$ However, in obiter dicta it recognized that "[t]he manner and extent to which Charter values should be weighed by universities in the course of administrative decision-making is factspecific." 113 While a complex body of case law exists on whether the Charter applies to universities, ${ }^{114}$ the BCCA in BCCLA presumed that Charter values applied. In turn, $B C C L A$ is emblematic of a phenomenon where quasi-public entities, such as universities, are presumed to or by their own volition adhere to Charter values. ${ }^{115}$

\footnotetext{
${ }^{109}$ See Doré v Barreau du Québec, 2012 SCC 12 at paras 24, 55; Loyola High School v Quebec (AG), 2015 SCC 12 at para 35.

1102016 BCCA 162.

111 Ibid at paras 11-12.

112 Ibid at para 59.

${ }^{113}$ Ibid at para 55.

${ }^{114}$ See Michael Marin, "Should the Charter Apply to Universities?” (2015) 35:1 NJCL 29 at 37-41.

115 See also McKitty $v$ Hayani, 2018 ONSC 4015 at paras 229-50. Although this was not expressly considered by the Ontario Superior Court, an underlying issue in the case was whether the hospital was compliant with Charter values in withdrawing life support from a "brain dead" patient who held a religious conviction that only cardiac arrest amounts to "death."
} 
Wall, however, potentially recalibrates the relationship between Charter values and quasi-public actors. Since Wall stipulates that only state agents are subject to judicial review, many quasi-administrative actors who may have sought to cohere with and promote Charter values will no longer be reviewed. The lack of judicial review is not necessarily indicative that such actors will abandon their practices. Rather, Wall creates an unintended consequence: the spread of Charter values is potentially impeded. That is, while the concept and application of Charter values has generated considerable debate, ${ }^{116}$ the Supreme Court has consistently held that Charter values play a critical role in our administrative law framework. ${ }^{117}$ Given this insistence, it would have made more sense for the court to ensure that Wall does not create an unintended incentive where quasi-administrative actors can choose not to comply with Charter values knowing that their failure to accord with Charter values may not be subject to judicial scrutiny.

In other words, it is widely accepted that where there is no remedy, there is no right. ${ }^{118}$ Similarly, with Wall, one may wonder: without judicial review, do we really know whether quasi-public bodies are respecting Charter values?

\section{CONCLUSION}

While Wall illuminated the first principles of judicial review, the decision unfortunately did not cure the primary problems associated with determining the scope of judicial review, especially in relation to quasi-public actors. The Supreme Court's solution in Wall to determining the scope of judicial review was to endorse an approach that markedly narrowed such scope. The result is that quasi-public or even technically private actors who perform integral functions in the modern administrative state might be immune from judicial review, and the spread of Charter values among such actors is potentially thwarted. Further, what is more problematic is that in Wall the court misinterpreted a helpful body of cases on the public-private distinction and further complicated when judicial review is available to litigants. In short, Wall's prima facie

\footnotetext{
${ }^{116}$ See e.g. Christopher D Bredt \& Ewa Krajewska, "Doré: All That Glitters is Not Gold” (2014) 67 SCLR 340; Audrey Macklin, "Charter Right or Charter-Lite? Administrative Discretion and the Charter" (2014) 67 SCLR 561; Hoi L Kong, "Doré, Proportionality and the Virtues of Judicial Craft" (2013) 63 SCLR 501; Matthew Horner, "Charter Values: The Uncanny Valley of Canadian Constitutionalism" (2014) 67 SCLR 361.

${ }^{117}$ For a detailed discussion, see Lorne Sossin \& Mark Friedman, "Charter Values and Administrative Justice" (2014) 67 SCLR 391 at 403-9, DOI: <10.2139/ssrn.2389809>. Sossin and Friedman note a wide array of decisions where the Supreme Court has over the years stressed the importance of Charter values. 118 See e.g. Marbury v Madison, 5 US 137 (1803), where Chief Justice Marshall observed that "[t]he government of the United States has been emphatically termed a government of laws, and not of men. It will certainly cease to deserve this high appellation, if the laws furnish no remedy for the violation of a vested legal right."
} 
simplification of the law of judicial review masks deeper conceptual and practical tensions.

Outlining a principled approach to determining the ambit of judicial review is not easy. In fact, in his 1936 article, Professor Borchard lamented that there was "the greatest confusion among the [common law] courts" on "the very foundation of judicial function": namely, what matters can be subjected to judicial review? ${ }^{119}$ In this regard, it is commendable that the Supreme Court did not avoid a juridical problem that has perplexed courts for decades. Rather, the court recognized the problem with isolating the scope of judicial review and offered a direct solution. Unfortunately, that solution does not meet the needs of ordinary Canadians and the modern administrative state. As the court stressed in Wall, judicial review is integral to achieving one of our highest ideals - upholding the rule of law. To achieve this objective, Wall must be reformulated in order to provide a solution that is both jurisprudentially sound and practically effective.

${ }^{119}$ Edwin Borchard, “Justiciability” (1936) 4:1 U Chicago L Rev 1 at 1. 